\title{
ARTIKELEN
}

\section{De betekenis van de verborgen kunst}

\author{
Marc Cools \& Dina Siegel
}

\section{Inleiding}

Kunst geeft schoonheid, kracht en wijsheid aan de realiteit van het verleden, het heden en de toekomst. De kunst, scheppende en uitvoerende net als de literatuur en de architectuur, staat evenzeer garant voor betekenis die zich laat vatten in de verbeelding. Dit laatste kwam al uitvoerig aan bod in het themanummer 'de kunst van het verbeelden' van ons tijdschrift waar werd stilgestaan bij de verbeelding van de criminaliteit in de beeldende kunsten (de Haan \& van Swaaningen, 2014). De kunst als een 'gift possessed by few' (Findlay, 2014) laat zich op een open manier het best omschrijven aan de hand van een aantal clusterkenmerken. Kunst wordt gekenmerkt vanuit de wil om te excelleren door een algemeen erkend artistiek medium te zijn, het hebben van opvallende esthetische eigenschappen, het ontsproten zijn aan de creatieve verbeelding, het getuigen van vaardigheid en kunde, het behoren tot een zeker genre en het aanzetten tot een emotioneel beroeren vanuit een eigen complexe betekenis. Kunst is evenzeer een evolutief en steeds veranderend gegeven op basis van nieuwe ideeën (Bird, 2019) en past als kunsthistorisch studieobject zeker binnen de culturele studies (D'Alleva, 2015).

In het raam van de kunstcriminaliteit hanteert men een ruime definitie van kunst. Men verwijst naar de 'schone kunsten', met inbegrip van schilderijen, foto's, prints tekeningen, beeldhouwwerken, decoratieve kunst, antiquiteiten, etnografische voorwerpen, 'oosterse' kunst en de als 'collectables' te omschrijven voorwerpen (Conklin, 1994). De criminologie en bij uitbreiding de culturele criminologie heeft altijd interesse getoond in kunst en de kunsten en heeft hiervoor meerdere invalshoeken gecreëerd. Ze kunnen het middel dan wel het voorwerp zijn om criminologische inzichten en kennis te verwerven of ze genereren een eigen en specifiek criminaliteitsfenomeen. Met betrekking tot de eerste verhouding, als een dynamische relatie (Vanderveen, 2014), kan worden verwezen naar kunst en de literatuur in het bijzonder als nuttige en nodige perspectieven om kennistoename in de criminologie te realiseren. Kunst kan optreden als een 'gevaarlijk weten' dat zich verhalend, auditief, beeldend en creatief voordoet. Ze kan het dominante denkkader van de criminologie ontregelen en macht, structuur, fenomeen, betekenis en symboliek (Cools, 2018) plaatsen binnen de 'cultures of deviance' en de 'cultures of control' (Ferrel et al., 2008). Individuele kunstenaars kunnen bovendien het kwade, de kracht van de criminaliteit, het analyseren van beelden en de representaties van misdaad en straf als geen ander uitdrukken.

De link tussen kunst en criminaliteit heeft een lange geschiedenis. Vertegenwoordigers van diverse kunststromingen en scholen hebben criminaliteit en de bestraffing daarvan verbeeld (de Haan \& van Swaaningen, 2014): de machtelozen versus 
de machtigen, het slachtoffer versus de beul. Doeken van Caravaggio, Rembrandt, El Greco, Goya of Botero tonen ons martelingen, bloedige executies, complotten, bedrog, oorlog, moord en verkrachting. Latere kunststromingen, zoals het kubisme en het surrealisme van Picasso en Dali, ook al stonden ze zelf politiek tegenover elkaar, vervingen dergelijke realistische en bloedige scènes door abstracte verbeeldingen van menselijke emoties, paranoïde gedachten en onbegrensde fantasieën. Cultureel criminologen proberen aan de ene kant de betekenis van criminaliteit en geweld in de kunst te begrijpen. Ze richten zich op de 'representatie' van criminaliteit en zoeken verklaringen voor waarom kunst ons emotioneel kan raken. Aan de andere kant bestuderen ze criminele handelingen rondom kunst, zoals kunstroof, vandalisme, smokkel of vervalsingen. Het gaat hier om motieven, modus operandi en de gevolgen van deze delicten. Het accent ligt daarbij op de vraag hoe het mogelijk is dat de kunstwereld - een wereld van schoonheid en rijkdom - zelf crimineel gedrag voortbrengt.

De kunstcriminaliteit, als één van de meest lucratieve vormen van criminaliteit (Charney, 2020), laat zich moeilijk definiëren, ook al bestaat er een zekere consensus met betrekking tot de brede fenomenen en de betrokkenheid erin van kunst en cultureel erfgoed: diefstal, fraude, vervalsing, roof en vandalisme en de kunstcrimineel. Met betrekking tot deze laatste denkt men vaak, alleszins in een Nederlandse context, aan bijvoorbeeld de figuur Michel van Rijn. Deze kunsthandelaar en -crimineel kwam ook weg met een meer dan lezenswaardige autobiografie Hot Art, Cold Cash (1993). Kunst kan daarentegen ook een middel zijn om criminaliteit te plegen dan wel eraan gerelateerd zijn. We denken hierbij aan: artnapping en afpersing (Tijhuis, 1994), witwassen (Shutten, 2000), cybercriminaliteit en belastingmisdrijven (Hufnagel, 2020; Conklin, 1994), de collusie tussen de legale boven- en de illegale kunstonderwereld (Koldenhoff \& Timm, 2020). Het criminologisch onderzoek naar kunstcriminaliteit, dat zeker meer wetenschappelijke aandacht verdient, wordt echter geconfronteerd met een gebrek aan bronnen, data en statistisch materiaal, wat ook kan leiden tot een zekere mythevorming (Conklin, 1994) ter zake.

In dit themanummer zullen we de betekenis van de verborgen kunst, die als het ware aan het oog van de rechtmatige eigenaar wordt onttrokken, verduidelijken door vooral aandacht te besteden aan de tweede invalshoek, met name de kunstcriminaliteit. Achtereenvolgens en eerder theoretisch bespreken we het gegeven van de legale kunsteconomie, de schimmige en criminele 'artopolis'. Kunst heeft een subjectieve economische waarde door haar schaarsheid. Laat dit nu juist de kern van het economisch denken zijn. Het maken van een keuze uit schaarse middelen met het oog op een zo hoog mogelijke nutsmaximalisatie. Dit brengt ons bij de verhouding tussen de kunst en de (criminele) economie die reeds lang een constante is. In wat volgt wensen we vooreerst de legale kunsteconomie te verduidelijken.

\section{De legale kunsteconomie}

De schaarsheid, de bijzonderheid, het unieke, de niet-reproduceerbaarheid, het fetisjkarakter en de exclusiviteit (De Graeve, 2008) van een kunstwerk als indicator voor haar economische waarde kan niet worden uitgedrukt in de verhouding arbeid 
en kapitaal, noch in goed of slecht, waardevol dan wel waardeloos, mooi of lelijk, doch moet eerder worden gezocht in haar nutswaarde (Mosselmans, 2001) of haar 'must have' (Findlay, 2014). Het zijn vervolgens de kunstendistributeurs die door de kunstenmarketing gebaseerd op plaats, prijs, product en promotie (Van Ryssen, 2001) de kunst kunnen vermarkten. De economische waarde van een individueel kunstwerk wordt medebepaald door de provenance. Dit is de gedocumenteerde herkomst, de staat waarin het zich bevindt, de authenticiteit, de kwaliteit, de uitstraling ervan, het historisch belang, de prijsevolutie (Robertson, 2016) en de grootte (Adam, 2018). De kunstwereld (Becker, 2008), die uiteraard groter is dan de kunstmarkt, kent een aantal actoren, zoals de kunstenaar, kunsthandelaar, kunstadviseur, verzamelaar, veilinghuizen, kunstbeurzen, biënnales, musea en kunstrecensenten en kunstcritici die als 'sleutelpersonen' de dienst uitmaken. De kunstmarkt bestaat in essentie uit een groep actoren die kijkt naar het verleden om de kunstwerken na authentificatie te verkopen en een andere groep die kijkt naar het heden om de '(ver)koop' na validatie met behulp van de kunstenaarsstichtingen, die garant staan voor de echtheid, te verwezenlijken (Robertson, 2016).

Deze legale kunsteconomie veronderstelt in de eerste plaats als kunstendistributeurs de aanwezigheid van kunsthandelaars of financiers du mystère met een vaak eigen en bijzondere persoonlijkheid in de wereld van de handel. Elk tijdperk had zo zijn eigen topkunsthandelaars (Thompson, 2010). We denken hierbij, en dit al sinds de zeventiende eeuw, aan bijvoorbeeld de Amsterdamse Hendrick van Uylenburgh en de Antwerpse Matthijs Musson als intermediairs tussen de kunstenaar en de klant. In het achttiende-eeuwse Parijs ontstonden de handelaars-connaisseur, type Edme-François Gersaint en Jean-Baptiste Pierre Le Brun, die de veiling als vertonende kunstmarkt introduceerden. Dit forum leidde dan weer tot het verstevigen van de interactie tussen de kunstenaar en de klant in de negentiende eeuw door onder meer Ernest Gambart en zijn bewuste aanpak om van de Londense kunsthandel een publiek evenement te maken. In de twintigste eeuw worden kunsthandelaars iconen. Joseph Duveen, actief tussen Londen, Parijs en New York, internationaliseerde de kunsthandel door kunstkennis te combineren met handel en kon de kunst een statussymbool doen worden (Thompson, 2010). Georges en Daniel Wildenstein werkten in Parijs samen met Paul en Léonce Rosenberg en zagen de kunsthandel als een vorm van warfare. Door kapitaalsaccumulatie konden ganse collecties worden verhandeld. Bovengenoemde kunsthandelaars keken vooral en letterlijk om naar oude(re) kunst. Het is met de komst van de in Parijs actief zijnde Paul Durand-Ruel, Ambroise Vollard, Daniel-Henry Kahnweiler en Alexandre Bernheim dat er interesse ontstond in het handelen met hedendaagse kunst. Naast het aanboren van nieuwe kunstmarkten ontstond ook de galerij, de 'branding' van kunstenaars en de prijscontrole. In Berlijn deden Paul Cassirer en Alfred Flechtheim hetzelfde en ook de vooral in Londen werkzame Otto Gutekunst, Hugh Lane en Alexander Reid kozen voor een identieke aanpak (Hook, 2017). Amsterdam, Antwerpen, Parijs en Berlijn ruimen echter sinds de jaren 1950 als kunsthandelscentra plaats voor Hongkong, Londen en New York (Thompson, 2018; Robertson, 2016). De daar aanwezige koopkracht maakte het voor bijvoorbeeld Peggy en Solomon Guggenheim, John Paul Getty en Henry Clay Frick (Findlay, 2014) mogelijk om de positie van handelaar en verzamelaar in te nemen die op hun beurt later 
een internationale marktomgeving creëerden voor bijvoorbeeld Leo Castelli, Larry Gagosian en Charles Saatchi (Hook, 2017; Thompson, 2010). Dit triumviraat staat voor meer dan een symbool voor de hedendaagse geglobaliseerde kunsthandel en de topkunsthandelaars. Ze hebben de kunst het statuut van een commodity doen krijgen. Dichter bij huis kan worden verwezen naar de kunsthandelaar Jan Six en de handel in Rembrandt (van de Wetering, 2018).

Naast deze bij wijze van voorbeeld genoemde iconische topkunsthandelaars of alpha dealers (Robertson, 2016) bestaan er natuurlijk ook nog de mainstreamkunsthandelaars, die vandaag in hoofdzaak zijn gevestigd in New York en Londen, en die als poortwachters functioneren. Ze bepalen zelf wiens kunstwerk al dan niet zal worden getoond. De highstreet galerijen, waar verkoper en kunstenaar dan weer samen de kosten delen om rendabel te zijn, staan een trap lager in de kunsthandelhiërarchie. In de vanity galerijen moet de kunstenaar zelf betalen om te worden tentoongesteld. De particuliere handelaar of de kunstadviseur, als laagste trede in de kunsthandel, sluit de hekken (Thompson, 2010). Nochtans gaan deze kunstadviseurs ervoor zorgen dat ze de kunstenaar en de kunstwerken in de markt kunnen plaatsen door deze vervolgens vooral te binden aan een koper (Thompson, 2018). Ongeacht hun grootte trachten alle galerijen de mythe van de exclusiviteit zorgvuldig in stand te houden (Baars, 2009) en een commissie te bedingen op de verkoop van tussen de 5 en de $50 \%$ van de verkoopprijs.

Ook de veilinghuizen nemen een belangrijke rol in de kunsthandel en de kunstenmarketing in. Het duopolie gevormd door Sotheby's en Christie's (Adam, 2018; Thompson, 2018), die toekomstige klanten zelfs leningen (Adam, 2018; Findlay, 2014) en financieel advies aanbieden (Shnayerson, 2019), zijn uiteraard de meest gekende. Ze worden met stip gevolgd door Phillips de Pury en Bonhams. Dit beperkte aantal topspelers leidde ook wel eens tot een bitse concurrentiestrijd en gaven soms aanleiding tot het bestaan van een auction house war (De Purry \& Stadiem, 2016). Het basisprincipe van alle veilinghuizen, als 'een colosseum dat op de duimen wacht' (Thornton, 2009) of een 'gladiator sport at the highest level' (Thompson, 2018), is echter dat van de alsmaar stijgende prijzen (Adam, 2018) of het 'ratchet'-effect en het bespelen van het 'endownment'-gevoel. Dit wil zeggen dat men tracht de koper meer te doen bieden dan wat hij zich had voorgenomen te betalen om toch maar niet het gevoel te krijgen om het kunstwerk alsnog niet in zijn bezit te krijgen. De veiling is een plaats waar het kunstwerk wordt 'gewonnen' (Thornton, 2009). Op de kijkdagen en de evenementen (Thompson, 2018) die tot doel hebben de mogelijke kopers te verleiden, al dan niet met een veilingcatalogus of een volledige catalogue raisonné van de kunstenaar(s), biedt de aanwezige veilinghuisspecialist extra cultureel en waardebepalend advies. De veiling zelf wordt geleid door de veilingmeester, die acteert als een ceremoniemeester (Thornton, 2009). Deze kan de veiling ophouden of het werk 'inkopen' (Conklin, 1994), als de minimumopbrengst, te weten 60 à $70 \%$ van het beste veilingresultaat van een vergelijkbaar kunstwerk, niet wordt gehaald. Vaak maakt men echter gebruik van de come-hither schatting. Men houdt de geschatte opbrengst in overleg met de inbrenger of verkoper, die een commissie krijgt, opzettelijk laag om het bieden door de kopers te stimuleren. Het toepassen van de 'lik-mijn-reet-dit-prachtige-werk-krijgje-nooit' impliceert het naar het niveau van de verwachte verkoopprijs of hoger 
tillen van de laagst geschatte opbrengst. De koper (musea, kunsthandelaars, curatoren, particuliere verzamelaars en de voor anderen ingehuurde 'veilingbabes') betaalt een nog hoger opgeld. De op een veiling bereikte hoogste prijs vormt een plafond dat richting geeft aan toekomstige prijzen en functioneert als een barometer voor de financiële waarde (Thornton, 2009).

De veilinghuizen hebben altijd op gespannen voet geleefd met de kunsthandelaars. Deze laatsten hebben de internationale en flink gepromote kunstbeurzen, als een 'must go' (Adam, 2018) voor de kunsthandelaars zoals Basel, Chicago, Frieze, Keulen, Londen, Maastricht en Miami (Shnayerson, 2019; Findlay, 2014; Thornton, 2009) als kijk- en koopevenementen voor de 'art-world-elite' (Findlay, 2014) kunnen gebruiken als tegenzet (Thompson, 2010). Deze kunstbeurzen werken met een toelatingscommissie, waardoor sommige galerijen kunnen worden geweigerd om deel te nemen (Thronton, 2009). We stellen vast dat deze kunstbeurzen zich vandaag ook richten op steden als Hongkong, Beijing, Abu Dhabi, Seoul, Moskou en Los Angeles (Findlay, 2014). Eenzelfde redenering gaat bij wijze van spreken op voor de biënnales. Deze vaak aan een stad gebonden reusachtige exposities geven aan wat er op dat moment op artistiek gebied in de wereld leeft (Thornton, 2009). De musea hebben eveneens als poortwachter het monopolie op de 'museale waarde' (Findlay, 2014), waardoor de prijs van een kunstwerk kan worden bepaald. De musea die een internationale merkenstatus ter zake hebben, zijn het Museum of Modern Art en het Metropolitan Museum of Art in New York, de National Gallery in Washington, het Getty Museum in Los Angeles, het Louvre in Parijs, het Prado in Madrid, de National Gallery, het Tate Modern en Tate Britain Gallery in Londen (Findlay, 2014), het Rijksmuseum in Amsterdam, de Hermitage in Sint-Petersburg en het Centre Pompidou in Parijs (Robertson, 2016). De internationalisering door middel van het oprichten van deelmusea in het buitenland of de zogenaamde 'McGuggenheimisatie' maakt van deze musea globale spelers (Thompson, 2018). Soms treden ze zelfs op als verkopers met kunstwerken uit hun eigen depots om vervolgens de aankoopbudgetten voor andere kunstwerken te verhogen (Baars, 2009). Ook de door de beide Tates ingestelde kunstprijs, de Turner prize, kan een indicatie zijn voor de economische waarde van de in opkomst zijnde kunst (Thornton, 2009). De kopers, al dan niet als megaverzamelaars zoals Bernard Arnault, François Pinault en Sheika al-Mayassa (Thompson, 2018) en al dan niet gedreven door ijdelheid, hoogmoed en winstvooruitzichten, ronden de economische kringloop af. Veel kopers, behoudens deze die zich enkel richten op de betaalbare schoonheid van een kunstwerk, verwachten dat er bij elke aankoop een 'give us a lift' (Findlay, 2014) zal ontstaan dat het loutere decoratieve overstijgt. Kunst als een 'decos', een trofee, een 'decoration' als een 'add-on' of een 'décoration' als een oogstrelende ervaring moet een investering, gebaseerd op de reputatie van de individuele kunstenaar en zijn werk worden (Findlay, 2014). Een investering die kan leiden tot speculatie (Thompson, 2018) en mogelijk gericht wordt op de nieuwe afzetmarkten of 'emerging markets' (Pryor, 2016) in China, Latijns-Amerika, het Midden-Oosten en Rusland.

De legale kunsteconomie kent bovendien een aantal bijzonderheden die het klassiek economische gebeuren van het, vaak toenemende, 'aanbod maakt de vraag', waardoor een natuurlijk evenwicht van de marktprijs, al dan niet binnen een vrije 
dan wel gereguleerde markt, ontstaat tussen verkoper en koper, enigszins anders kenmerken. Het aanbod van kunstwerken, zeker de oudere, op de secundaire markt (Findlay, 2014) van het doorverkopen is vast dan wel, voor de hedendaagse, zeer vrij (Vande Veire, 2008), waardoor de kunstmarkt een vragersmarkt wordt en de keuze van de kopers in tijd, ruimte en voorkeurskunststroming bepalend is voor de prijs, prijsschommelingen en monetair rendement (Fase, 2008). Er bestaan evenzeer art indexes om zich omtrent de kunstmarkt te informeren en er door analyse gevolgen uit te trekken (Findlay, 2014).

De aanbieders, in al hun diversiteit, van de in hoofdorde hedendaagse kunstwerken trachten hierop in te spelen door een aantal specifieke methoden te hanteren naar de kunstenaar toe. Het spreekt voor zich dat niet alle veilinghuizen, de jaarlijkse kunstbeurzen en de galerijen deze gebruiken. Het steeds opnieuw op zoek gaan naar nieuwe kunstenaars, die al spreekwoordelijk kunnen worden gemaakt dan wel worden gekraakt bij hun 'first drop' (Findlay, 2014) door kunstrecensenten en kunstcritici, en deze voor de eerste maal te kunnen verkopen op de primaire markt met een hoge commissie lijkt wel op een war for talent. Het komt er dan ook op aan om deze kunstenaars zo vlug als mogelijk individueel te binden (Shnayerson, 2019) aan de kunsthandelaar door het geven van leningen, voorschotten of regelmatige vergoedingen. De kunstenaars zelf zeggen dan weer exclusief toekomstig werk toe. Om af te rekenen met het zogenaamde 'Van Gogh-syndroom', men hoeft niet te wachten op het overlijden van de kunstenaar (Findlay, 2014) om zijn kunst in waarde te doen stijgen. We denken bijvoorbeeld aan Koons, Hirst, Banksy en anderen. Men kan de kunstenaar ook 'plaatsen', en vooralsnog zijn kunstwerken niet verkopen, in bijvoorbeeld een museum of in een tentoonstelling. De hierdoor ontstane aandacht en informatiedoorstroming, als marktinformatie over de kunstenaar en zijn werk zullen de prijzen, als gevolg van deze branding doen toenemen. Het komt er ook op aan de signalling van de kunstenaar en zijn werk op te volgen door ervoor te zorgen dat de prijzen consistent blijven (Thompson, 2010). De kunstrecensenten en de kunstcritici die werken voor bijvoorbeeld de kunsttijdschriften zoals Artforum International, Artnews, Art in America en Frieze, kunnen ook de economische waarde van de kunst door hun lovende of vernietigende kritieken, op de soms bestaande 'kunstwereldkwakzalverij', meer dan beïnvloeden en steeds nieuwe interpretaties op de kunstmarkt loslaten (Thornton, 2009).

Om vandaag een betrouwbaar en wetenschappelijk verantwoord zicht te krijgen op de totale kunstmarkt wordt vaak verwezen naar het werk van Clare McAndrew (Findlay, 2014), oprichtster van Arts Economics die in samenwerking met Art Basel en UBS al voor de vijfde maal het rapport The Art Market publiceerde. In 2020 daalde de kunstmarkt met 22\% en $27 \%$ ten overstaan van respectievelijk de jaren 2019 en 2018, vooral op de kunstmarkten in de Verenigde Staten van Amerika, het Verenigd Koninkrijk en China, die samen $82 \%$ van de totale kunstmarkt uitmaken. In 2020 bedroeg de omzet nog steeds $\$ 50,1$ miljard, waarvan $\$ 12,4$ miljard online en $\$ 29$,3 miljard door de kunsthandelaars werd gerealiseerd. De veilinghuizen namen een verkoop van $\$ 17,6$ miljard op zich (McAndrew, 2021). 
De schimmige en criminele kunsteconomie en de kunstcriminelen functioneren onder, binnen en boven de ruime artopolis (De Pury \& Stadiem, 2016), die soms kan verworden tot wat men een ware cultuur van exces (Van Stokkom \& Schuilenburg, 2020) zou kunnen noemen. De actoren, zoals de kunstenaars, topkunsthandelaars, mainstram-, highstreet- en vanity-galerijen, particuliere handelaars, kunstadviseurs, verzamelaars, veilinghuizen, kunstbeurzen, biënnales, musea, kunstrecensenten en kunstcritici zijn er actief in een grensoverschrijdende en fluide kunstmarkt (Pryor, 2016). Het gegeven dat de legale kunsteconomie de minst gereguleerde en de minst transparante handel (Thompson, 2010) ter wereld is en waar men bovendien als koper en verkoper anoniem kan handelen, zelfs door middel van een onderhandse (Baars, 2009) transactie, maakt deze bijzonder aantrekkelijk voor schimmige en criminele fenomenen. Dit is de kern van ons criminologisch betoog met betrekking tot de verdoken kunst.

De schimmigheid van de legale kunsteconomie komt vooreerst en zeker tot uiting bij de veilinghuizen en de freeports. Het veilingproces kent een aantal technieken die de normale concurrentiële economische transactie bezoedelen. We denken aan de knock-out veiling, waar er tussen de handelaars afspraken worden gemaakt om niet tegen elkaar te bieden en nadien het verschil tussen de reguliere veiling en de uiteindelijke overeenkomst onder elkaar te verdelen. Ook het 'bod-poolen', ofwel het samen bieden om een derde uit te sluiten, en de 'sealed-bid', het op voorhand afspreken wie werkelijk biedt, zijn veilingrealiteiten (Thompson, 2020). Men kan ook werken met fictieve biedingen of de 'bidding off the chandelier' (Conklin, 1994). Veel veilinghuizen aanvaarden ook het verhandelen, zonder provenance, van echte, valse (Charney, 2020a; Adam, 2018), ongeautoriseerde en zelfs gestolen (Couwenhoven, 2017) uitgaven (Baars, 2009) en kunstwerken. Ook het bestaan en het gebruik van de freeports als dark rooms (Koldehoff \& Timm, 2020) zoals er zijn in Genève, Hongkong, Luxemburg, Peking, Singapore en Zürich dragen bij tot de niet-transparante koop en verkoop. De freeports zijn zwaarbewaakte en beveiligde ruimtes (Shnayerson, 2019) die hun ontstaan te danken hebben aan de Zwitserse freeport king Yves Bouvier. Hij schiep, onder impuls van de toegenomen kunsthandel in de 'high-end' producten en de hieraan verbonden investeringen en speculaties, een belastingvrije ruimte waar de uber-rich hun kunst konden bewaren, tonen en verhandelen of flippen uit het zicht van eenieder. Deze secret back-room handel met inbegrip van het bestaan van geheime commissies bieden natuurlijk ook hier mogelijkheden tot het witwassen van crimineel geld (Koldehoff \& Timm, 2020; Adam, 2018).

De rol van musea in deze illegale kunstmarkt varieert van het negeren van ontbrekende eigendomsgeschiedenissen tot het verbergen van waardevolle collecties, betrokkenheid bij het verdwijnen van stukken uit museumdepots, het certificeren van vervalsingen als authentieke objecten en het niet teruggeven van geroofde of gesmokkelde kunst aan de rechtmatige eigenaren (staten of individuen) (Van Beurden, 2001; Rottenberg, 1999).

In deze context staan de kunsten en de kunst als een voorwerp ook niet los van de politieke en maatschappelijke inbedding. De dichotomie tussen de Hochkultur en 
de underground culture (Mortier, 2001) maakt een opening die ons toelaat te verwijzen naar de verboden of de gecensureerde kunst. Deze kunst wordt door haar verboden zijn, ontbloot en obsceen (Hertmans, 2015). Daar waar bijvoorbeeld de erotische kunst min of meer oogluikend werd toegelaten, kon dit niet worden gezegd van de pornografische kunst en bij uitbreiding van de pornografie (Vermeersch, 1987) op zich. De toepassing van de censuur op deze vormen van kunst, de literatuur in het bijzonder, is al zo oud als de literatuur zelf (Aarts \& Van der Pluijm, 1989).

Met betrekking tot het politieke kunnen de kunsten een utopische en/of ideologische wegwijzer zijn. Ze duiden wat nationaal, internationaal, vrij, ontaard, kitsch, decadent, formeel of louter propagandistisch is. Ze werden een graadmeter van de politieke identiteit (Segal, 2015). Dit werd overduidelijk in de door de totalitaire regimes vooropgestelde kunsten als een Gesamtkunstwerk (Sers, 2014). In het fascistische Italië werd de Novecento, het futurisme met haar militaire agressie, snelheid en technologie (Phillips, 2018) alsook het magisch realisme omarmd. Hetzelfde gold voor het nationaalsocialistische Duitsland, dat de scheidslijn tussen de kunsten die het Volkskörper, de Volksgemeinschaft en de Nackedei (Meulenkamp, 2014) verzinnebeelden centraal stelde ten overstaan van de verdorven Entartete Kunst (Gamboni, 2018; Peters, 2014). De communistische Sovjet-Unie koos dan weer voor de maakbaarheid van de nieuwe mens binnen het socialistisch realisme (Giusti, 2014). Ook in de huidige democratieën kunnen sommige kunstvormen nog altijd als schandaalkunst (Baucheron \& Routex, 2013) worden weggezet en politiek worden verketterd. Dit gaat vandaag zelfs nog op voor de zogenaamde le neuvième art van het stripverhaal, waar de censuur ook alomtegenwoordig is (Smet, 2020) en zoals later wordt aangegeven geldt dit ook en meer en meer voor de 'besmette' koloniale collecties als roofkunst (van Beurden, 2021).

\section{De aan het oog van de rechtmatige eigenaar onttrokken verborgen kunstcriminaliteit}

In dit themanummer werpen verschillende auteurs hun licht op de verborgen kunst. Het artikel van Mathias Desmet inzake plundering onder het mom van iconoclasme als bron voor illegale handel in antiquiteiten legt de verbinding tussen het iconoclasme of kunstvandalisme, de roofkunst, de georganiseerde misdaad en de financiering van het terrorisme door het witwassen. Een ideale gelegenheid om bijvoorbeeld het iconoclasme en de roofkunst van ook antiquiteiten (Balestrieri, 2019) in het bijzonder van nader te bekijken. Het iconoclasme als het beschadigen en/of vernietigen van kunst om politieke, religieuze, ideologische en moralistische redenen is van alle tijden. Met de beeldenstorm, de Franse Revolutie en de val van de communistische wereld in het achterhoofd kan men vandaag het iconoclasme als een vorm van cultureel terrorisme, censuur of zelfs als een kunst op zich zien. Het begrip roofkunst, zoals onlangs nog weergegeven in de reeks Roofkunst door BNNVARA onder regie van Hans Pool en gepresenteerd door Erik Dijkstra in het Rijksmuseum, het AfricaMuseum, het British Museum en het Neues Museum (Van der Kooi, 20221), wordt vereenzelvigd met het stelen en het illegaal uitvoeren van kunst en/of cultuurgoederen. Deze laatste categorie kenmerkt zich in hoofdzaak 
door de cultuurhistorische waarde ervan (Gimbrère, 1997). Roofkunst wordt vaak in verband gebracht met revoluties en oorlogen (Tompkins, 2016). Of nog 'Mars en Minerva zijn doch noyt de beste vrienden gheweest' (Brosens, 2014). Het werk van de kunstdetective Arthur Brand toonde dit aan inzake de schat van Carchemish 2015) en de paarden van Hitler (2019). Een aantal andere voorbeelden behoren tot de canon van de roofkunstgeschiedenis. We denken bijvoorbeeld aan het Louvre, de Elgin Marbles, het Führermuseum, de Carinhall, de Aanbidding van het Lam Gods en de Adele Bloch-Bauer I.

Het Louvre, of later en kortstondig het Musée Napoléon, is het spreekwoordelijke kind van drie ouders. Het republicanisme, het anticlericalisme en de oorlog (Charney, 2018). De geroofde koninklijke, de prinselijke en de kerkelijke kunst (Krul, 2014) sieren de opbouw van de kunstverzameling van dag één. De door Frankrijk en Napoleon Bonaparte gevoerde oorlogen, in bijvoorbeeld België, Duitsland, Italië en Nederland, maakten de collectie door roofkunst, voorbereid door de voor de overheid optredende Commission Temporaire des Arts, volledig (Gould, 1965). Met betrekking tot de van het Parthenon in Athene afkomstige friezen, de Elgin Marbles (Marijnissen, 2002), die zich in het British Museum te Londen bevinden, en destijds weliswaar gekocht werden door Lord Englin van het Ottomaanse bestuur in Constantinopel, kan men zich de vraag stellen of ze daar wel thuishoren. Ook de door de Einsatzstab Reichsleiter Rosenberg, waarover later meer, geroofde kunst die finaal zou hebben gediend om het Führermuseum in Linz (Charney, 2018) als een Sonderauftrag en met een Führervorbehalt (Schwarz, 2014) inhoud en uitstraling te geven, past in deze rij. Net als de inrichting van Herman Görings kunstschat en kunstverzameling (Alford, 2012) in zijn te Schorfheide tot museum omgevormde Carinhall (West, 1991) en de ontdekking in 2012 van de kunstschat, bestaande uit 1400 kunstwerken, aan entartete en gestolen kunst door Hitlers kunstdief Hildebrand Gurlitt (Schwarz, 2017).

Met betrekking tot een aantal unieke kunstwerken die het voorwerp werden van roofkunst kunnen we niet om de Aanbidding van het Lam Gods heen (Charney, 2018; Schutten 2000), dat in Gent werd geroofd en opnieuw gerestitueerd in maar liefst drie oorlogen. De Franse revolutionaire en de Eerste en de Tweede Wereldoorlog (Charney, 2011). Het portret van Adele Bloch-Bauer I behoort ook tot deze categorie. Dit werk werd door de nationaalsocialisten gestolen en pas na een lange juridische strijd terugbezorgd aan de rechtmatige eigenaars (Sandmann, 2018). Hetzelfde ging in Nederland op voor de roof en restitutie bij bijvoorbeeld de Joodse kunsthandelaar Jacques Goudstikker (Alford, 2012) en in Frankrijk bij Paul Rosenberg (Sinclair, 2012). Het stuk van Marc Cools over Nico Gunzburg en het 'Moskou-archief' behandelt de acties van de Einsatzstab Reichsleiter Rosenberg die uiteindelijk aanleiding zullen geven tot het bestaan van het 'Moskou-archief' en past in bovengenoemde historische tijdsgeest. Het verwijst naar het bestaan van de quiet crime in de kunstcriminaliteit, met name de diefstal van boeken en documenten. Deze kunnen, om ideologische redenen, als een trofee in oorlogstijd worden beschouwd.

Yasmina Zian bespreekt in haar the Belgian debate on restitution since 2018 - a perspective on the political acts shaping het vraagstuk van het postkoloniale gegeven dat in de culturele studies aandachtig wordt bestudeerd en de koloniale roofkunst en 
roof van cultureel erfgoed en culturele eigendom. In Nederland leeft of zou dit zeker moeten leven met betrekking tot bijvoorbeeld de externe of afstandskoloniën: Indonesië, Suriname en de Antillen (Van Beurden, 2020) en in België inzake Congo. Men kan zich zelfs de vraag stellen waarom in het Westen de relatie tussen de naziroofkunst, als slachtoffer, en de koloniale roofkunst, als dader, niet altijd wordt gelegd (Van Beurden, 2020).

Het Museum van Belgisch-Congo in Tervuren als voorbeeld van 'beschaving', 'vooruitgang' en imperiale triomf bagatelliseert het postkoloniale verleden (Silverman, 2014) van België in haar voormalige afstandskolonie. De renovatie en het herdopen van dit museum in het AfricaMuseum heeft de discussie tussen de vooren de tegenstanders van het al dan niet restitueren (Tsirogiannis, 2019) van de koloniale collecties opnieuw op scherp gesteld. Vooreerst was er in Congo het vernietigen van de ceremoniële en de religieuze voorwerpen door de missionarissen, als een vorm van religieus geïnspireerde culturele genocide en vervolgens het 'verzamelen' door de ambtenaren, de missionarissen, de wetenschappers en de handelaars van Congolese authentieke kunst. Dit alles destijds ter promotie van de eigen kolonisatiepolitiek en vandaag als een vorm van bescherming (Van Beurden, 2020). De bijdrage van Dina Siegel over misdaad tegen de kunst: de Russische avant-gardewereld sluit naadloos aan bij het bestaan van de censuur en de politieke identiteit in verhouding tot de criminalisering van de avant-gardekunst, het bestaan van een 'niet-officiële' kunst en clandestiene collecties. Er wordt bijzondere aandacht besteed aan het gegeven van de experten en de vervalsingen.

Naast de reeds eerdergenoemde kunstrecensenten en kunstcritici bestaan er ook experten of connaisseurs die een garantie kunnen bieden voor de echtheid of de valsheid van de kunstwerken van deze of gene kunstenaar of kunstenaarsgroep. Hun professionalisme, of gebrek eraan, kan leiden tot schandalen met betrekking tot het op de kunstmarkt brengen van valse kunstwerken (Koldehoff \& Timm, 2020). Vanuit een historische context bekeken, is het 'geval' Han van Meegeren meer dan beroemd. Deze vervalser, 'more prankster than gangster' (Moses, 2020), van de schilderijen van Vermeer wordt dikwijls in verband gebracht met het bij de neus nemen van meerdere internationale experten tot en met deze van de nationaalsocialisten toe (Charney, 2015). Hij gaf door deze vervalsingen een andere betekenis aan het werk ((Vanderveen, 2014). Dit gaat ook op voor bijvoorbeeld de vervalsingen van de werken van Vincent van Gogh (Charney, 2020b; Tromp, 2006) en al de Cobra-werken die werden geproduceerd door Geert Jan Jansen (Charney, 2015; Jansen, 2005).

Het essay Voor roem of fortuin: vervalsingen van archeologische objecten van Noah Charney, die zoals blijkt uit de literatuurlijst van onze inleiding één van de autoriteiten in het domein van de kunstcriminaliteit is en oprichter van de Association for Research into Crimes against Art, richt zich op een aantal beroemde gevallen van vervalste archeologische objecten, zoals het James Ossuarium, de Lijkwade van Turijn, de Piltdownmens en het Archaeoraptor fossiel.

In Voorbij de horizon sluit Martina Althoff dit themanummer af met het Bauhaus, modernieteit en de Unrechtstaat. De bij veel kunstliefhebbers bestaande fascinatie voor het Bauhaus en de Bauhäusler als kunstrichting enerzijds en als helden en verzetsstrijders tegen het nationaalsocialisme anderzijds wordt van haar mythes 
ontdaan. Het Bauhaus, haar beoefenaars en aanhangers zijn niet langer alleen maar de slachtoffers, doch nemen ook de plaats in van de (mede)daders. Besluiten kunnen we dit themanummer met een quote van niemand minder dan Andy Warhol: 'Art is anything you can get away with' (Thompson, 2018). Dit geldt zeker als een dubbele bodem voor de aan het oog van de rechtmatige eigenaar onttrokken verborgen kunst.

Verder komt ook nog Peter Cohen aan het woord die in het essay Het verdienmodel drugs en de vooruitziende blik van de commissie-Hulsman. Kort verhaal over een Inquisitie op een kritische wijze het in 2020 door Pieter Tops en Jan Tromp gepubliceerde boek Nederland drugsland: De Lokroep van het geld, de macht van de criminelen, de noodzaak die te breken (en hoe dat dan te doen) analyseert met het oog op een verdere en een meer realistische discussie.

\section{Literatuur}

Aarts, C. \& M. van der Pluijm (1989). Verboden boeken. Verboden door pausen, dictators, puriteinen en boekenhaters. Amsterdam: Uitgave Magazijn De Bijenkorf.

Adam, G. (2018). Dark Side of the Boom. The Excesses of the Art Market in the 21ste Century. Londen: Lund Humphries.

Alford, K. (2012). Herman Göring and the Nazi Art Collection. The Looting of Europe's Art Treasures and Their Dispersal After World War II. Jefferson: McFarland \& Company.

Balestrieri, B. (2019). The Antiquities Licit-Illicit Interface. In S. Hufnagel \& D. Chappell (Eds.), The Palgrave Handbook on Art Crime (pp. 79-87). Londen: Palgrave.

Barron, S. (1992). Entartete Kunst. Das Schicksal der Avantgarde im Nazi-Deutschland. Los Angeles: Museum Associates.

Baucheron, E. \& D. Routex (2013). The Museum of Scandals. Art that Shocked the World. Paris: Prestel.

Becker, H. (2008). Art Worlds. Berkeley: University of California Press.

Bird, M. (2019). 100 ideas that changed art. Londen: Laurence King Publishing.

Brand, A. (2015). Het verboden Judas-evangelie en de schat van Carchemish. Soesterberg: Uitgeverij Aspekt.

Brand, A. (2019). De paarden van Hitler. Hoe de kunstdetective zijn sensationeelste ontdekking deed en wereldnieuws werd. Amsterdam: Meulenhof.

Charney, N. (2009). Art Crime in Context. In N. Charney, Art and Crime. Exploring the Dark Side of the Art World (pp. xvii-xxv). Santa Barbara: Praeger.

Charney, N. (2011). Het Lam Gods. 's Werelds meest begeerde Meesterwerk. Amsterdam: Uitgeverij Luitingh.

Charney, N. (2015). Kunstvervalsingen. Misleiding en masterminds van meestervervalsers. Houten: Terra.

Charney, N. (2018). The Museum of Lost Art. Londen: Phaidon Press.

Charney, N. (2020). Kenmerken van kunstcriminaliteit. Justitiële verkenningen, 46(4), 9-27.

Charney, N. (2020a). Interview with Arthur Brand. The Journal of Art Crime, 109-112.

Charney, N. (2020b). A Real van Gogh: How the Art World Struggles with Truth. Henk Tromp. The Journal of Art Crime, 93-94.

Conklin, J. (1994). Art Crime. Westport: Praeger.

Cools, M. (2018). Curzio Malaparte: een culturele criminologische reis. In R. De Corte, M. De Vos, P. Humblet, F. Kéfer \& E. Van Hoorde, De Taal is Gans het Recht, Liber Amicorum Willy van Eeckhoutte (pp. 459-479). Mechelen: Wolters Kluwer Belgium.

D'Alleva, A. (2015). Methods \& Theories of Art History. Londen: Laurence King Publishing. 
De Graeve, P. (2008). Processies - over de kunst als heilige en de kunst als hoer. In I. Dusar \& H. Meersman. Markteconomie en Kunst (pp. 25-35). Leuven: Acco.

de Haan, W., van Swaaningen, R. (2014). De kunst van het verbeelden. Tijdschrift over Cultuur \& Criminaliteit. (4). Den Haag: Boom Lemma Uitgevers.

Den Hollander, P. (2007). Roofkunst. De Zaak Goudstikker. Amsterdam: Meulenhoff.

De Pury, S. \& W. Stadiem (2016). The Auctioneer. Adventures in the Art Trade. New York: St. Martin's Press.

Fase, M. (2008). Beleggen in schilderkunst. In I. Dusar \& H. Meersman (red.), Markteconomie en Kunst (pp. 105-116). Leuven: Acco.

Ferrel, J., K. Hayward \& J. Young (2008). Cultural Criminology. Londen: Sage.

Findlay, M. (2014). The Value of Art. Munich: Prestel.

Gamboni, D. (2018). The Destruction of Art. Iconoclasm and Vandalism since the French Revolution. Londen: Reaktion Books.

Giusti, M. (2014). Art et Dictature au XXe siècle. Paris: Editions Place des Victoires.

Grimbère, S. (1997). Het Unidroit-verdrag. Over de internationale bescherming van cultuurgoederen. Justitiële verkenningen, (1), 8-17.

Hook, P. (2017). Rogues' Gallery. A History of Art and its Dealers. Londen: Profile Books.

Houpt, S. (2007). Vermist uit het museum. Tielt: Lannoo.

Jansen, G. (2005). Magenta. Amsterdam: Prometheus.

Koldehoff, S. \& T. Timm (2000). Kunst und Verbrechen. Berlijn: Galiani.

Lopez, J. (2020). De laatste Vermeer. Han van Meegeren, vervalser en verrader. Amsterdam: Prometheus.

Marijnissen, R. (2002). The Case of the Elgin Marbles. Gent: Ludion.

McAndrew, C. (2021). The Art Market 2021. Basel: Art Basel and UBS.

Meulenkamp, W. (2014). Totalitair naakt. Het vrouwenlichaam in de beeldcultuur van het Derde Rijk. Soesterberg: Aspekt.

Moses, N. (2020). Fakers, forgeries and frauds. Lanham: Rowman \& Littlefield.

Mosselmans, B. (2001). De economie van kunst en cultuur: contradictio in terminis? In B. Mosselmans, Kunst te Koop. Bruggen en breuken tussen kunst en economie (pp. 43-62). Roeselare: Roularta Books.

O'Connor, A.-M. (2012). De Dame in Goud. Het verhaal van Klimt's beroemde portret in handen van de nazi's. Amsterdam: Meulenhoff.

Peters, O. (2014). Degenerate Art. The Attack on Modern Art in Nazi Germany, 1937. Munich: Prestel.

Phillips, S. (2018). Moderne en hedendaagse kunst begrijpen. Kerkdriel: Librero.

Pryor, R. (2016). Crime and the Art Market. Londen: Lund Humpries.

Robertson, I. (2016). Understanding Art Markets. Inside the World of Art and Business. Londen: Routledge.

Rottenberg, H. (1999). Meesters, marodeurs. De lotgevallen van de collective-Chardzjiev, Amsterdam: Uitgeverij Jan Mets.

Rush, L. (2016). Looting and Antiquities. In A. Tompkins (Ed.), Art Crime and its Prevention (pp. 180-190). Londen: Lund Humphries.

Saatchi, C. (2009). My name is Charles Saatchi and I am an Artoholic. Londen: Phaidon.

Sandmann, E. (2018). Der gestohlene Klimt. Wie sich Maria Altmann die Goldene Adele zurückholte. Berlijn: Insel Verlag Berlin.

Schiphof, T. (1997). Kunstvandalisme. Vernieling, verwaarlozing en het 'droit au respect' van de kunstenaar. Justitiële verkenningen, 23(1) 54-62.

Schulten, K. (2018). Kunstroof 1795-1815. Nederlands bezit in Franse handen. Zutphen: Walburg Pers.

Schutten, H. (2000). Kunstmaffia. Moord, diefstal, oplichting en witwaspraktijken in de kunstwereld. Amsterdam: Meulenhoff. 
Schwarz, B. (2014). Het Führermuseum van Hitler. In J. Tollebeek \& E. van Assche (Eds.), Ravage. Kunst en cultuur in tijden van conflict (pp. 197-204). Brussel: Mercatorfonds.

Schwarz, B. (2017). Hildebrand Gurlitt and the Special Commission Linz. In A. Berset \& M. Grütters (Eds.), Gurlitt Status Report (pp. 48-55). Bern: Kunstmuseumbern.

Segal, J. (2015). Kunst \& politiek. Tussen zuiverheid en propaganda. Amsterdam: Amsterdam University Press.

Sers (2014). Le détournement de l'art par le pouvoir totalitaire. In M. Giusti, Art et Dictature au XXe siècle (pp. 6-13). Parijs: Editions Place des Victoires.

Shnayerson, M. (2019). Boom. Mad Money, Mega Dealers and the Rise of Contemporary Art. New York: PublicAffairs.

Silverman, D. (2014). De identiteit van een koloniale schatkamer. In J. Tollebeek \& E. van Assche (red.), Ravage. Kunst en cultuur in tijden van conflict (pp. 2019-224). Brussel: Mercatorfonds.

Sinclair, A. (2012). Rue de La Boétie 21, memoires. Antwerpen: De Bezige Bij.

Smet, J. (2020). Duizend bommen en castraten. Censuur in de strip. Antwerpen: Uitgeverij Vrijdag.

Thompson, D. (2010). Shock Art. Handel en hebzucht in de hedendaagse kunst. Amsterdam: Uitgeverij Walewein.

Thompson, D. (2018). The orange balloon dog. Bubbles, turmoil and avarice in the contemporary art market. Londen: Aurum Press.

Thornton, S. (2009). Art. Achter de schermen van de kunstwereld. Amsterdam: De Bezige Bij.

Tompkins, A. (2016). Art in War. In A. Tompkins, Art Crime and its Prevention (pp. 180-190). Londen: Lund Humphries.

Tromp, H. (2006). De strijd om de Echte Vincent van Gogh. De kunstexpert als brenger van een onwelkome boodschap 1900-1970. Amsterdam: Mets \& Schilt.

Tsirogiannis, C. (2019). Illicit Antiquities in American Museums: Diversity in Ethical Standards. In S. Hufnagel \& D. Chappell (Eds.), The Palgrave Handbook on Art Crime (pp. 815838). Londen: Palgrave.

Van Beurden, J. (2020). Dubieuze verwervingen en het Advies over de omgang met koloniale collecties. Justitiële verkenningen, 46(4), 63-75.

Van Beurden, J., (2021). Ongemakkelijk erfgoed. Koloniale Collecties en Teruggave in de Lage Landen. Zutphen: Walburg Pers

vande Veire, F. (2008). Het fetisjkarakter van het kunstwerk en zijn geheim. In I. Dusar \& H. Meersman (red.), Markteconomie en Kunst (pp. 117-125). Leuven: Acco.

Vanderveen, G. (2014). Criminaliteit en kunst. Betekenisgeving aan verbeeldingen. Tijdschrift over Cultuur \& Criminaliteit, (2), 99-108.

Van de Kooi, W. (2021). Alles gaat voorbij behalve het verleden. De Groene Amsterdammer, 1-4.

Van Rijn, M. (1993). Hot Art. Cold Cash. Londen: Little, Brown and Company.

Van Ryssen, S. (2001). De intrede van Aaker in www.art.be: marketing en kunsten. In M. Mosselmans (red.), Kunst te Koop. Bruggen en breuken tussen kunst en economie (pp. 89-118). Roeselare: Roularta Books.

Van Stokkom, B. \& M. Schuilenburg (2020). Macht, misdaad en exces. Enkele inleidende reflecties. Tijdschrift over Cultuur \& Criminaliteit, (1), 3-17.

Van de Wetering, E. (2018). In Six, J. Rembrandts Portret van een jonge man. Amsterdam: Prometheus.

Vermeersch, P. (1987). Het slijk der zinnen. Pornografie in België. Leuven: Uitgeverij Kritak. 